Article

\title{
The Samaritan and Jewish Versions of the Pentateuch: A Survey
}

\section{Ingrid Hjelm}

Faculty of Theology, University of Copenhagen, 1165 Copenhagen, Denmark; ihj@teol.ku.dk

Received: 15 November 2019; Accepted: 6 February 2020; Published: 12 February 2020

check for updates

\begin{abstract}
This article discusses the main differences between the Samaritan and the Jewish versions of the Pentateuch. The Samaritan Bible consists of the Torah-that is, the Five Books of Moses-also called the Samaritan Pentateuch (SP). The Jewish Bible contains in addition the Prophets and the Writings, a total of 39 books. The introduction seeks to present both traditions in their own right and in relation to other ancient textual traditions (the Dead Sea Scrolls, the ancient Greek and Latin, and the Septuagint). The focus of this article is on the shared tradition of the Pentateuch with special emphasis on the textual and theological character of the Samaritan Pentateuch: major variants in the SP, the Moses Layer, and the cult place. This article closes with discussion of editions and translations of the Samaritan Bible and the Masoretic Bible respectively.
\end{abstract}

Keywords: Samaritan Pentateuch; Jewish Masoretic Bible; variant traditions; Moses; cult place; editions and translations

\section{Introduction}

The Samaritan, Jewish and Christian Canons differ in regard to the number of books included. The Samaritan canon consists only of the Five Books of Moses, which is the Torah (Law) and by scholars called the Samaritan Pentateuch (SP). These books also form part of the Jewish canon, which we call the Hebrew Bible (HB), the Masoretic Tradition (MT) or the TaNaK. In addition to the Law (Torah), the Hebrew Bible also contains the Prophets (Neviim) and the Writings (Ketuvim) - a total of 24 books (4 Ezra 14:45) or 22 books (Josephus, Against Apion, 1.38) in ancient counting. Counting each book individually, this gives 39 books. The Torah also forms part of the Christian Greek (the Septuagint $=\mathrm{LXX}$ ) and Latin (the Vulgate) Bibles. These bibles include all of the books of the Hebrew Bible with various numbers of additional books from the so-called Apocryphal and Pseudepigraphical literature.

As this publication's focus is on Samaritanism, our concern regards the Torah in these traditions. They basically share the same storyline, beginning with the creation of the world, the Patriarchs, the origin of the Israelites, the Exodus, the wandering in the desert, the giving of laws, and ending with the death of Moses at the entrance of the Promised Land. Stemming from different sources and undergoing an unknown number of redactions, the Samaritan, Jewish and Christian bibles also expose a considerable number of formal, lexical and theological variations. Since the first comparisons in the seventeenth century, it is generally claimed that the SP contains 6000 variants in regard to the MT-1900 of which correspond with the LXX. ${ }^{1}$ Most of these are grammatical and formal, related to spelling and punctuation, with great variations in regard to both the MT and SP manuscripts. Such minor variants may be insignificant, but quite a number have theological implications. In addition, 40 major variants between the SP and the MT are narrative and ideological. These variants, in spite of shared similarities between the ancient traditions, have challenged assumptions of an origin in a common proto-Masoretic

1 On this, see (Purvis 1968; Tov 1992; Pummer 2007). 
Jewish source produced in the first millennium BCE. Based on the existence of different text types among the Dead Sea Scrolls, it is now concluded that the SP belongs to a so-called expansionist text type, which differs from the proto-Masoretic texts that later became the MT. Most scholars, however, still consider the SP as originating from Jewish circles and secondarily adapted to Samaritan theology. Other scholars (Nodet 1997; Macchi 1994), including myself (Hjelm 2000, 2015), maintain that a proto-Pentateuch originated in Samaritan circles and that the formation of a nearly uniform tradition with distinct Samaritan and Jewish characteristics was a common work between Jewish and Samaritan priests and scholars in the Persian and Hellenistic periods (fifth to second century BCE). Based on recent evidence of the religio-political situation in the province of Shomron in the early Persian period, (Knoppers 2013, pp. 169-94)) re-evaluated the questions of origin and development and concluded that the early Pentateuch was altogether a common work between Aaronide priests on Gerizim and in Jerusalem. He nevertheless upheld the traditional opinion that the SP underwent sectarian revisions in the second to first century BCE (Knoppers 2013, p. 188). Such a derogative view on Samaritan belief and literary traditions unfortunately have been pervasive in scholarship. It was based on the assumption that Samaritans originated from apostate priests that had left Jerusalem's temple in order to establish a competing cult place on Mt. Gerizim. Given what we now know about the religio-political situation and the origins of the Samaritan religion in the Persian province of Shomron, it no longer makes sense to view the province of Judah's and Jerusalem's cult and traditions as normative over against other Yahwist cults in antiquity. These religious communities developed concomitantly and independently in their own right as far as the reigning superpowers gave permission to. The term 'sectarian' does not apply to such activity.

The early Hebrew texts were consonantal texts written in ancient Hebrew (paleo-Hebrew) and Aramaic scripts. The Aramaic language was the lingua franca from the Persian period and its script became preferred in Jewish writings. The Samaritans knew and used this script also as can be seen from the Mt. Gerizim inscriptions, but they have kept until now the paleo-Hebrew script, in a form that stems from around the turn of the era, for their sacred writings. That Judaism embraced the new "Assyrian" (Ashshurith) script and Aramaic language led rabbis of the fourth century CE to criticize the Samaritans for keeping the old script (b. Sanh. 21b). In order not to support Samaritan claim for scriptural authenticity, an additional argument stated that the Torah was originally given in Ashshurith, then changed into paleo-Hebrew and back again to Ashshurith, the "upright" (me'ushshar) script (b. Sanh. 21b; Kartveit 2009, p. 289).

While Samaritans and Jews fought over the antiquity and authenticity of the various Torah editions, New Testament authors invariably used Torah texts that reflect the SP, the MT and the LXX. Patristic authors, such as Origen, Eusebius of Caesarea, Epiphanius and Cyril of Jerusalem, also knew and referred to the SP "without prejudice for the Jewish text" (Montgomery 1907, p. 286). Eusebius compared ancient chronologies in the Samaritan Pentateuch, a Jewish pre-Masoretic Bible and the Septuagint, and he claimed the Samaritan version the more original (Pummer 2002, pp. 77-88). Jerome made use of the SP in his translation of the Vulgate (Anderson 1989, p. 390), and as late as Syncellus, who died in the early ninth century, it was (still) considered the oldest text, by Jews also. In his Hexapla, Origen quotes readings, which he marked to Samareitikon, and it was assumed that it referred to an ancient Greek translation of the SP (Montgomery 1907, p. 285; Noja 1989; Pummer 2002, p. 42). Pummer, however, seriously questioned this assumption and it remains uncertain whether the Samaritans had a Greek translation of the SP or whether Origen's to Samareitikon references are to Greek variants shared by the Samaritans also (Pummer 1995, 1998; Crown 2001, pp. 15-17). In Jan Joosten's recent examination of Greek Fragments of the SP, he considers these to be a Samaritan adaptation of the Septuagint, containing specific Samaritan readings (Joosten 2015; cf. Pummer 2016, p. 210).

It is evident from such use and also from the great variety of texts among Dead Sea Scrolls that Hebrew Scriptures were not standardized or authorized before the Common Era and that so-called vulgar and expansionist texts were common. These texts are defined by insertions of "source" texts from one biblical book to another in order to remove linguistic and theological ambiguities. The SP 
belongs to this text type. It shares an orthographic closeness to the DSS in its comparable use of plene (full) spelling and matres lectionis, using certain consonants as vowels for spelling and reading purposes (Macuch 1969; Purvis 1968, p. 86; Hjelm 2000, p. 91). The SP is not part of the DSS manuscripts, but some fragments of these bear such formal resemblance to the SP that they have been labeled pre-Samaritan texts. ${ }^{2}$ Apart from a shared Moses-veneration, their content is not specifically Samaritan, and it is far-fetched to conclude that they display a pre-Samaritan level which eventually led to the SP when "the Samaritans chose one text-type in particular among the different texts available" as Kartveit does in his 2009 book (Kartveit 2009, p. 299). According to this view, the Samaritans changed the chosen text to accord with their own theology in the first century CE (Kartveit 2009, p. 295) or later as has been suggested by Crown (1991, p. 47; Crown 2004, p. 2254). We have no evidence for such conclusions, and they rest on several fallacies about text production in antiquity, the shared Samaritan and Jewish religious and literary traditions and the history of each people in the Persian and Hellenistic periods (Hjelm 2000, 2004b, pp. 19-30; 2012a).

\section{Characteristics of the SP}

As mentioned above, the SP belongs to a text-type called expansionist texts. Compared to the MT, it contains several minor and major additional variants-some of which are found in other ancient texts also. Main theological characteristics of the SP relate to the exceptional status of Moses as Yahweh's prophet and to Yahweh's choice of the proper cult place. The first is shared with some of the aforementioned DSS texts, while the second has not been found in non-Samaritan texts. In addition to shared orthographic, lexical and theological details with DSS, the SP also share several minor details with the Old Greek Mss, Vetus Latina, Pseudepigrapha, the Septuagint, the New Testament, Jewish Targumim, Syriac Peshitta and the Vulgate.

\section{Major Variants in the SP}

Since Gesenius' seminal analysis of the SP in the early nineteenth century, it has been customary to describe deviations between the MT and SP as additions or interpolations into the SP. Gesenius termed such variants additamenta maiora e locis parallelis interpolata (major expansions interpolated from parallel passages), thereby indicating a priority not only of the Masoretic text, but also of Deuteronomy, which in most cases is considered the source text of the additions. ${ }^{3}$ Avoiding such a priori assumptions, I prefer to use the term "major variants" for so-called additional texts and "minor variants" for textual differences that are not, or only to a lesser degree, sizable. Most of the major variants can be found in SP Exodus and Numbers.

The 19 major variants in SP Exodus are basically found in the Exodus narrative (ch. 6-11), the Decalogue (ch. 20) and the designs for the tabernacle (ch. 26-29). ${ }^{4}$ Five of SP Exodus' variants (18:25; 20:17, 19, 21; 32:10) parallel passages in Deuteronomy.

The 16 major variants in SP Numbers are found in two narrative sections in chapters 10-14 (5 passages) and 20-27 (nine passages) framed by variants belonging to cultic regulations in 4:14 and 31:20. ${ }^{5}$ Main themes of the two narrative sections regard the promise and inheritance of the land, the people's fear of taking the land and Yahweh's anger and punishment.

The composition of SP Numbers 10-14 forms a continuous narrative, which is concluded in the detailed conquest scenes in chapters 20-21. A red thread through these chapters and Deuteronomy's

2 These are $4 \mathrm{Q} 17=4 \mathrm{QExod}-\mathrm{Lev}^{\mathrm{f}}, 4 \mathrm{Q} 22=4 \mathrm{QpaleoExod}{ }^{\mathrm{m}}, 4 \mathrm{Q} 27=4 \mathrm{QNum}{ }^{\mathrm{b}}$, + the five Reworked Pentateuch texts: 4Q158 $=$ RPa , $4 \mathrm{Q} 364=R P^{\mathrm{b}}, 4 \mathrm{Q} 365=R P^{\mathrm{c}}, 4 \mathrm{Q} 366=\mathrm{RP}^{\mathrm{d}}, 4 \mathrm{Q} 367=\mathrm{RP}^{\mathrm{e}}$. (Kartveit 2009), also adds $4 \mathrm{Q} 175$.

3 (Gesenius 1815, 46-48). (Kartveit 2009, 310-12, chart 1 and 2), has added passages to Gesenius' list.

4 Exod 6:9; 7:18, 29; 8:1, 19; 9:5, 19; 10:2; 11:3; 18:25; 20:17, 19, 21; 26:35; 27:19; 28:29; 29:28; 32:10; 39:21. The variants in SP Exodus (minus SP's mention of Gerizim as the cult place in the Decalogue in ch. 20) are all found or restored in 4QpaleoExod ${ }^{\mathrm{m}}=$ 4Q22 (DJD IX, 67); cf. (Sanderson 1986; Skehan et al. 1995; Kartveit 2009, pp. 310-11).

5 Num 4:14; 10:10; 12:16; 13:33; 14:40, 45; 20:13 (x2); 21:11-12, 20-23; 27:23; 31:20 Of the 16 variants in SP Numbers, 10 are found or restored in 4Q27; in 6 cases no extant text was found; cf. (Kartveit 2009, pp. 311-12). See also (Tov 1989, 1992, pp. 80-100). 
summary is woven of itinerary information of where Yahweh ordered the Israelites to go and what to do. In contrast, MT Numbers 10-14 lacks such coherence and mostly leaves the initiative of where to go and what to do to Moses. It rather focuses on the people's rebellion in three narratives: the quails (chp. 11), Miriam and Aaron's rebellion (chp. 12) and the spy narrative in 13-14.

The major variants in SP Numbers 20-27 are concentrated in chapters 20-21 narrating the second arrival at the border of the Promised Land in Qadesh and the initial conquests of the Amorites in the Transjordan. The variants begin and conclude with the appointment of Joshua as Moses' successor in chapters 20 and 27 paralleling texts in Deut 3:24-28 and 3: 21-22 respectively. Most of the variants are also found in 4Q27, but they are not in the LXX.

Two major variants are present in SP Deuteronomy (2:7 and 10:6). The variant to Deut 2:6 confirms, together with major variants in SP Numbers 20-21, that Edom, Moab and Ammon had been warned about the Israelites' intention of going through their lands without attacking them. ${ }^{6}$ The variant to Deut 10:6 'repeats' itinerary information from Num 33: 31-37.

All the 14 variants in Numbers 10-14 and 20-27 parallel passages in Deuteronomy, while those in Deuteronomy parallel passages in Numbers and Deuteronomy.

Literary examination of the Samaritan Pentateuch's major variants (Hjelm 2015, 2018), has demonstrated that SP's major variants create a consistency in SP Exodus and Numbers, which is missing in the Masoretic text, but found also in some of the Dead Sea Scrolls. The variant Samaritan traditions are not based on a proto-Masoretic Vorlage as it is not a Masoretic text, but a Samaritan text of Deuteronomy-that is, the "source text" for SP Numbers' variants (for detailed analysis, see, Hjelm 2018). This commonly used term "source text" (Tov 1992, pp. 88-89)—is somewhat misleading as it implies that a shorter J text in Numbers has been enlarged by insertions taken from a D text in Deuteronomy. By such assertions scholars implicitly support John van Seters' hypothesis that J is younger than D and the Deuteronomistic History and that "all of the parallel narratives in Deuteronomy are the sources of those in Exodus-Numbers" (Van Seters 2013, p. 349; Van Seters 1994, passim; Hjelm 2015, pp. 186-67). This line of development, however, is not a widely accepted assertion and most scholars interpret MT Deuteronomy 1-3's summaries as reflections of narratives in Exodus-Numbers. In regard to SP's major variants, however, most scholars bluntly redirect the relationship and assume that the "additions" stem from Deuteronomy's summaries.

A close analysis of SP's major variants has revealed that verbal correspondence between Numbers and Deuteronomy 1-3 is a rare phenomenon in MT texts, but usual in SP texts and the aforementioned DSS texts (for detailed analysis, see Hjelm 2018).

Although Deuteronomy 1-3 has the form of a summary, it is striking that in MT Deuteronomy 1 's 46 verses only few correspond (partly) with the wording in Numbers, for example Deut 1:9 par. Num 11:14; Deut 1:24 par. Num 13:23; Deut 1:25 par. Num 14:7; Deut 1:35-36 par. Num 14:23-24; Deut 1:39 par. Num 14:31; Deut 1:40 par. Num 14:25; Deut 1:41-45 par. Num 14:40-45. The rest reads as conflating paraphrases of Exodus-Numbers; for example the appointment of leaders in Deut 1:9-18 with parallels in Num 11:16-17, 24-25 and Exod 18:18-26; and the spy narrative in Deut 1:23-40 with its parallel in Numbers 13-14, but alluding also to Exodus 14 and 19. ${ }^{7}$ The small narrative section (Deut 1:41-45 par. Num 14:40-45) about the failed attack on the Amorites // Amalekites and Canaanites exposes the highest degree of verbal correspondence, without being, however, a verbatim reproduction. Also the 66 verses of MT Deuteronomy 2-3 contain only a small number of isolated verses that parallel partly with these of MT Numbers 20-21; for example Deut 2:1 par. Num 21:4; Deut 2:30 par. Num 21:23; Deut 2:32 par. Num 21:23; Deut 2:33b par. 21:24a; Deut 3:3b par. Num 21:35. It is only in Deut 3:1-2 that we find a complete similarity with the parallel text in Num 21:33-34. The exact verbal correspondence

6 These variants are also found in 4Q364, which “agrees in several details with SP Numbers 20 and Deuteronomy 2 as opposed to MT Numbers" (Tov and White 1994, p. 231).

7 For detailed discussion of Deuteronomy's correspondence with Exodus-Numbers, see (Nelson 2002), passim. 
between Deut 3:1-2 and Num 21:33-34 is interesting, because it is similar in character to the major variants in SP Numbers (Hjelm 2018, pp. 28-30).

Two basic features appear from my examination of SP's major variants in Exodus and Numbers: (1) most of these regard Yahweh's or Moses' direct speech in Deuteronomy; and (2) SP's major variants have a higher degree of verbatim correspondence between Deuteronomy and their Tetrateuch (Genesis-Numbers) parallels than we see in parallel passages, which we find in both SP and MT (Hjelm 2018). The latter speaks for a conscious redaction, with insertions of texts from one scroll to another. The direction of dependence, however, is not entirely clear, because the variants are fully integrated in the narrative composition of both SP Deuteronomy and Numbers.

\section{The Moses Layer}

The so-called "Moses layer" (Kartveit 2009, p. 280) emphasizes Moses' exceptional status as receiver of the Law. Moses is thus presented as a receiver of a divine message in more instances in the SP than in the MT. This is especially the case in chapters 6-11 of Exodus' plague narrative, where a fuller story is created by narrating that Moses and Aaron actually went to Pharaoh and warned him by saying what Yahweh ("thus said the Lord") had told him in the preceding verses (Exod 7:18, 29; 8:19; 9:5, 19). "Thus said the Lord" is first introduced in Yahweh's instruction to Moses in Midian (Exod 4:22) and it is repeated in the first warning to Pharaoh in 5:1-3. Altogether, the phrase appears 16 times in SP's Exodus narrative and 9 times in MT's. A different pattern of congruence is found in SP Exod 10:2 and 11:3, where the action is told, but it is Yahweh's words to Moses that are narrated in $\mathrm{SP}$ and missing in the MT. Rather than being viewed as insertions in the SP, the additional passages appear, in fact, as missing text in the MT, which leaves out the encounter between Moses and Pharaoh. A critical reader of the MT may say that Pharaoh had not been warned. All these variants to the Exodus narrative are found also in the DSS manuscript 4Q22/4QpaleoExod ${ }^{\mathrm{m}}$.

Literary correspondence can also be observed regarding SP's literary congruence between the Moses narrative in Exodus-Numbers and Moses' testimony in Deuteronomy. These are missing in MT but found in so-called pre-Samaritan DSS texts (Tov 1989, 1992, pp. 80-100. Together with an emphasis of Deut 18:18-22's true prophet in the Decalogue in Exodus 20, Moses appears in the SP as a truthful mediator of Yahweh's words recorded in the Torah, which succeeding prophets merely preach. The portrait may reflect a Samaritan polemic against the biblical prophets and 'an emphasis on the original Law of Moses over against newer revelation' (Kartveit 2009, p. 285). The "Yahweh said" and "Moses said" passages in Exodus-Numbers gives the deity the role of controlling the history and places Moses in the role of prophet and interpreter. While the narrator of Exodus-Numbers reports what Yahweh and Moses did and said in the past, Deuteronomy's author presents Moses as speaking and giving testimony of Yahweh's words and deeds (e.g. Deut 1:5; 4:1; 5:1;31:1), yet writing it down $(31: 9,24)$ to be read and taught by the Levites (31:11-12). In such composition, Deuteronomy's author, who remains mostly in the background of his narrative, establishes Moses as the true prophet of Deut 5:23-31 and 18:15-22, whose teaching successive interpreters must imitate. As stated by Simeon Lowy:

'The references to Moses in Scripture [are] not the words of Moses himself, but what "the Lord wrote of him". This tradition was the cornerstone of Samaritan belief throughout all generations, and the polemics against the Jews were invariably based on the assumption that no other authority whether of prophets or sages, whether in written or oral form, may be placed alongside or supersede this all-embracing unique revelation'. (Lowy 1977, p. 86)

In regard to SP's major variants, it is not Moses' but Yahweh's role, which is emphasized, and especially Numbers 20-21 underscore the deity's presence in the midst of his people, securing a successful outcome of their conquests. The "Moses layer" may serve to make "it even more evident that Moses had prophetic authority" and "primacy" (Kartveit 2009, p. 281), but taken together, SP's major variants serve a larger purpose, which also emphasizes Joshua's role as Moses' successor. 


\section{The Cult Place}

So-called heretical or schismatic additions and alterations in the SP relate to Yahweh's choice of Hargerizim as the proper cult place. Among them is the different wording of the Decalogue (Ten Commandments) in Exodus 20 and Deuteronomy 5 and the sanctioning of cult place(s) in Deuteronomy 12.

In the Decalogue of the SP, the first commandment is read as a headline. Following Exod. 20.17b and Deut. 5.18b, a tenth commandment is formed of Deut 11:29a; 27:2b-3a, 4a, 5-7 and 11:30 (in this order). These texts command that after the crossing of the Jordan, the Israelites shall bring the 12 stones to Gerizim and build there an altar of un-hewn stones. Reflecting contemporary discussions of the proper location, the commandments state that Gerizim is facing Gilgal at Elon Moreh with the further addition that it is facing Shechem. This precision, supported by rabbinic discussions (m. Sot. 7.5), has been considered a late redaction of the SP, following the final split towards the end of the second century BCE. None of these readings are found in pre-Samaritan texts, but the sections are either missing or the text is corrupt. Exodus 20 of 4QpaleoExod ${ }^{\mathrm{m}}$ also contains parallels with Deut 5:24-27. A lacuna in the text allows for another large variant: either the passage about the cult place that is also found in SP Deut 5:18 (cf. Deut 11:29a + 27:2b-6 + 11:30), or the verses as in Deut 18:18-22 (about

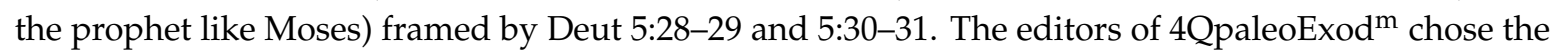
Moses option, based on logical considerations and similar arrangements in 4Q158 and 4Q175 (4QTest) (Skehan et al. 1995, pp. 66-68; Sanderson 1986). I think that their considerations are correct and support the obvious, namely that the DSS are not Samaritan. Even though 4QpaleoExod ${ }^{\mathrm{m}}$ (4Q22) comes closest to the SP, it also shares minor variants and readings with the LXX and the MT that are not in the SP.

Another key text employed in scholarly discussions about the location of the cult place, is Deuteronomy 12's utterance about "the place Yahweh "has chosen" (SP) or "will choose" (MT). The use of past "has chosen" or future "will choose" tense either points backwards to Gerizim in Deut. 11.29 (SP) or forwards to 1 Kings 8 and the inauguration of Solomon's temple (MT). That the question was well alive in the Roman period is testified in e.g. Josephus' Antiquities, the Gospel of John, and pseudepigraphic literature (Mendels 1987, 1992; Hjelm 2000, pp. 276-78; Hjelm 2004a, pp. 258-62). Scholars have usually considered that the past tense "has chosen" was a late ideological correction in the SP. Adrian Schenker has, however, pointed out that this reading is also found in some manuscripts of the LXX and in Coptic and Latin translations of Old Greek texts of the Torah (Schenker 2010; Schorch 2011). Based on these independent dispersions of what has been termed a Samaritan reading and supported by textual evidence from Neh 1:9 and Deut 30:1-4, both Schenker and Schorch consider the past tense the original. Such conclusion and Heckl's discussion of Schenker and Schorch (Heckl 2017) imply the fallacy that there was a single uniform text in antiquity from which all texts developed. With DSS, we know that this was not the case. From a religiopolitical viewpoint, it should be expected that priests and officials from Jerusalem and Mt. Gerizim developed each their own version(s).

Samaritan arguments against the Jewish reading are given in Late Medieval Samaritan Chronicles, which militate against the assumption that Moses would have left the question unanswered. Samaritan theology relies on the common tradition of Deut 11:29, which in both SP and MT commands that the blessings be placed on Hargerizim after the crossing of the Jordan. From this it logically follows that in Deuteronomy 12, the chosen place must be that mountain. Samaritan Joshua traditions affirm the location in parallel texts to MT Jos 8:30-35. Based on Deut 11:29; 27:4-6 and 12-13, these create a coherent narrative, when Joshua builds an altar on Mt. Gerizim rather than the Mt. Ebal found in MT's and LXX's placing of the blessing on Mt Gerizim (Deut 12:29; 27:12-13) and the altar on Mt. Ebal (Deut 27:4-6 and Jos 8:30/9:2).

A support for the Samaritan reading of Gerizim rather than Ebal in Deut 27:4 is found in the non-Samaritan DSS text fragment of Deut 27:4-6 (Charlesworth 2009, 2010; Ulrich 1994, 2017). In line with Vetus Latina and Pap. Giessen (Kartveit 2009, pp. 302-5), this first-century BCE fragment reads Hargerzim in Deut 27:4. In Knoppers' analysis of Deut 27:4 he argues that The MT reading of Mt. Ebal 'probably represents a later Judean correction' (Knoppers 2013, p. 203). 
Early Rabbinic and Patristic literature sought to downplay Samaritan claims for priority by arguing that the biblical Gerizim and Ebal were not to be found near ancient Shechem, but near Jericho. In Sifre Deut. 56 and in y. Soța 7.3, it is said that Rabbi Eliezer (ben Hyrcanus, second half of the first century CE) claimed that the Israelites erected two heaps of stones near Gilgal and named them Gerizim and Ebal. The idea was taken up by Eusebius in his Onomasticon 64.9-20. He meant that the mountains at Neapolis were too far apart for the people to be able to hear each other. His argument has been repeated by Epiphanius of Salamis (De gemm. 88.30-96.21; cf. Pummer 2002) and Procopius of Gaza (Comm. in Deut. 11.29) and it was initially accepted by Jerome (Lib.loc. 65.9-21). A few years later he seems to have changed his mind (Epist. 108 from 404; cf. Pummer 2002). There was, in fact, no evidence for the Jericho argument (Hjelm 2004a, pp. 198-202) and the location of biblical Gerizim and Ebal at Shechem/Neapolis was well established in writings of Josephus, the Mishnah (Sota 7.5), the Tosefta (Sota 8.7) and the Babylonian Talmud (b Sota 33b). Nevertheless, the discussion made an iconographic impact on the Madaba map (sixth century CE), which depicts two mountains in both places: near Jericho with their names written in Aramaic spelling and near Neapolis written in Greek forms (Pummer 2002, p. 87). The artist thus displays an interpretative distinction between an asserted biblical location and the geography of his own time, which also seems the case in the writings of Jerome, Epiphanius of Salamis and Procopius of Gaza. Origen in his Commentary on the Gospel of John 4 rejects Gerizim on the reason that it means "separation" or "division" referring "to the time when the people were divided by Jeroboam and the king dwelt in Samaria" (Origen, Comm. in Joh. 13.13.82). Combining Jesus' words: "but you say in Jerusalem is the place to worship" with another saying: "Christ calls this Jerusalem the city of the great king", Origin established an argument for Jerusalem's superiority (13.83). Origen goes as far as denying that the Samaritans should have received the Law first together with the Jews, citing Amos 6.1: "Woe to those who reject Mount Zion and trust in the Mountain of Samaria", for they make themselves strangers to the writings of God by rejecting the prophets (Comm. in Rom. 2.14). It is not the Scripture of the Samaritans, which is rejected by Origen, but Samaritan interpretation of the common tradition.

\section{Editions and Translations}

Most modern editions of both the SP and MT rest on medieval manuscripts from the ninth to the thirteenth century CE. These stem from earlier forms produced by Samaritan and Jewish communities since the second half of the first millennium BCE.

\subsection{The Samaritan Bible}

The Abisha Scroll is possibly the oldest scroll of the Samaritan Pentateuch and according to its colophon, which begins at Deut 6:4 (10), it was written by Abisha, the great grandson of Aaron in the 13th year after the settlement of the Israelites in the land of Canaan. That would, in modern chronology, date it to the mid second millennium BCE. A scribal note dates the scroll to $1065 \mathrm{CE}$, while modern scholars argue that it stems from the middle of the twelfth century CE (1149) and has been patched with later additions due to corruption of the original manuscript (Pérez-Castro 1953). A marginal note in the genealogical chronicle Tulida from 1346 relates that the scroll is kept in custody in the High Priest's house in Shechem (Bowman 1954, p. 45; Crown et al. 1993, p. 5; Florentin 1999, p. 69). (Gaster 1925, pp. 110-12)), assumed a very early original (fifth to fourth century BCE), which is not unlikely, given that the cult place on Mt. Gerizim was built in the fifth century BCE. The Scroll is greatly honored by the Samaritans and nowadays it is kept in custody in the synagogue in Luzah.

The first modern publications of a manuscript of the SP are those of the Paris and London Polyglots (many-tongues/languages), based on a manuscript acquired by Pietro della Valle in $1616 .{ }^{8}$ Until then, the Samaritans were practically unknown to most people in the Western World. Post-Reformation 
Christian discussions over Scripture had spurred Lutherans and Catholics to search for the original text of the Hebrew Bible (textus receptus). This also furthered a growing interest in Samaritan literature and tradition. Leading scholars from Western universities entertained life-long correspondence with Samaritan communities, enhancing studies in all forms of Samaritan literature. Many persons could be mentioned, but here it must suffice to mention: Julius Scaliger (sixteenth century), who acquired a copy of the Samaritan Book of Joshua from the Samaritan community in Cairo; Pietro della Valle, who in 1616 bought the first two copies of the Samaritan Pentateuch to be published in Europe as part of Johannes Morin's Polyglot from 1631; Robert Huntington from the late seventeenth century, who let the Samaritans believe that they had relatives in England; Hadrian Reland, with three publications on Samaritan issues, 1707, 1747 and 1765; from the nineteenth to twentieth centuries, we must mention Henry Maundrel, Silvestre de Sacy, Heinrich Peterman and John Mills; Abraham Firkovich, whose enormous collection of Samaritan and Karaite manuscripts are now in the National Library of Russia in St. Petersburg; E. K. Warren, whose collection of Samaritan manuscripts and artefacts is now in the possession of Michigan State University (the Chamberlain-Warren Samaritan Collection). He supported a school for the Samaritan children from 1903-1916. Moses Gaster, whose correspondence with the Samaritans and collection of manuscripts is now in the John Rylands Library, Manchester; and John MacDonald, who took a lifelong interest in Samaritan matters. ${ }^{9}$

The result is that there are today hundreds of manuscripts of the Samaritan Pentateuch and other Samaritan writings and documents in libraries worldwide. The majority of the SP manuscripts stem from Damascus, Egypt, Nablus/Shechem and Zarepthah (Anderson 1989, p. 395).

Della Valle's SP manuscript was printed alongside a manuscript of the Samaritan Targum (ancient translation of the SP into Aramaic) with a Latin translation that served both texts. The SP manuscript dated to 1345/46 and it was one of the major manuscripts of Von Gall's edition from 1918. Although he presented the then available manuscripts and also made use of them in his text critical apparatus, he, for unknown reason, chose a manuscript, which had several errors, had been reconstructed on the basis of MT and did not contain the Abisha Scroll (Hempel 1934, pp. 254-74). Lack of other available editions, nevertheless, gave it a status of being the Samaritan Pentateuch.

Abraham and Ratzon Tsedaka from the Samaritan community published a comparable edition of the Jewish and Samaritan Version of the Pentateuch (Tsedaka and Tsedaka 1961-1965). This version used a manuscript written in Sareptah in 1195, for the Tetrateuch and the Abisha scroll for Deuteronomy, with a Masoretic text in parallel columns. In 2000, Israel Tsedaka made a fully vocalized version of this manuscript in Samaritan Script (Tsedaka 2000). Both were produced by the Samaritan community.

Also, Luis F. Girón-Blanc's, Pentateuco Hebreo-Samaritano-Genesis, from 1976, sought to correct some of the mistakes of previous editions (Girón-Blanc 1976). Giron-Blanc's edition was based on MS. Add. 1846, written early in the twelfth century CE and kept in the University Library of Cambridge. This edition records variants from fourteen additional sources (Tov 1992, p. 84).

A recent comparative edition by Abraham Tal and Moshe Florentin from Tel Aviv University is based on the Hebrew manuscript of a tri-lingual Samaritan Torah in Hebrew, Aramaic and Arabic (Tal and Florentin 2010). It was written in Damascus in 1204 and brought to Nablus in 1625. The Hebrew manuscript MS 6 (C) Shechem was first published by Tal in 1994 (Tal 1994). Regrettably this manuscript contains many mistakes and is not considered representative of the SP by the Samaritan community. It deviates in many instances both from the manuscript published by A. and R. Tsedaka (1961-1965) and from the Samaritan reading tradition recorded by Ben-Hayyim in volume 4 of his oeuvre, The Literary and Oral Tradition of Hebrew and Aramaic Amongst the Samaritans (Ben-Hayyim 1957-1977; Schorch 2004; Tsedaka 2011; Hjelm 2012b). It is therefore not recommendable for detailed linguistic studies unless compared with other editions. Such had already been undertaken by Mark Shoulson, who in a

9 For bibliographic references, see (Schur 1989, pp. 116-20; Anderson 1977, 1989; Harvainen and Shehadeh 1994; Anderson and Giles 2002, pp. 2-5, 73-81, 91-107; and Anderson and Giles 2012, chp. 8). 
non-annotated comparative edition sought to overcome some manuscript problems by correcting Tal's 1994 edition of MS 6(C) Shechem against the manuscript used by A. and R. Tsedaka (Shoulson 2008).

The ambitious German-Hungarian Samaritan Pentateuch project conducted by Stefan Schorch and Jozsef Zsengellér, has published its first volume, The Samaritan Pentateuch. A Critical Editio Maior, Vol. 3. Leviticus, with Schorch as principal author (Schorch 2018). Its main manuscript is from 1225 and compared with 24 other SP manuscripts as well as ancient witnesses, it offers valuable insight into ancient and medieval text production.

In 2013, Benyamim Tsedaka published the first comparative edition of the SP and MT in English translation (Tsedaka and Sullivan 2013). It rests on the same Samaritan manuscripts as A and R. Tsedaka's edition. Providing, indeed, very different English translations of the Hebrew manuscripts, the average reader is led to believe that Samaritan and Jewish Torah traditions differ more substantially than is the case with the Hebrew texts.

The SP has been translated into Western Aramaic already in the first century BCE (Tal 1980-1983) and into Arabic from the eleventh century CE (Shehadeh 1989, 2002).

\subsection{The Masoretic Bible}

Proto-Masoretic texts from DSS date to the second to first century BCE and later, but it was only in the sixth to tenth century CE that they got their final Masoretic forms, which are used in worship and research. There never was a unified tradition that one might call "the Masoretic Text", but three systems of vocalization: Tiberian, Palestinian and Babylonian, and within these systems there was more than one family. Before the twentieth century, most editors of MT manuscripts created eclectic texts from a number of different manuscripts. Masoretic texts consist of several families-of which, the Aleppo (925 CE) and Leningrad (1009 CE) manuscripts belonging to the ben Asher Tiberian system have gained status as textus receptus in modern editions and scholarship. Biblia Hebraica (Stuttgartensia) (BHS; until 1967: BH or BHK) represent an edition—of which, its principal text for its first two editions (1905 and 1913) was the second Rabbinic Bible sponsored by Daniel Bomberg and printed in Venice in 1525. This Bible was not based on a single manuscript, but on a compilation of several carefully chosen and edited manuscripts. Emanuel Tov states about this edition:

'The second Rabbinic Bible became the determinate text for all branches of Jewish life and subsequently also for the scholarly world. All subsequent editions, with the exception of a few recent ones, reflect this edition, and deviate from it only by the change or addition of details according to manuscripts, or by the removal or addition of printing errors' (Tov 1992, p. 78).

The third edition of BH (1929-1937) and subsequent editions of BHS belong to the category "recent edition", based on Leningradensis (B19A), written in Old Cairo (Fustat) by the scribe Samuel ben Jacob in 1009. This is also the principal manuscript in the critical Biblia Hebraica Quinta, and in Aharon Dotan's edition from 2001, תורה נביאים וכתובים. Biblia Hebraica Leningradensia, which is a fully revised and retype set edition of the תורה נביאים וכתובים, published in 1973 with several corrected printings until 1986. The foreword to the 2001 edition states the following:

'We have produced here an edition of one of the oldest Masoretic witnesses of the complete Hebrew Bible, in a format ideal for the scholar, teacher and student. It is our aim, however, to produce an accurate Bible suitable for Jewish ritual use as well. Therefore, though keeping exactly to the text of the Leningrad manuscript, we were occasionally obliged to deviate from it for the sake of customs and conventions that have become rooted since the time the manuscript was written' (Dotan 2001, pp. x-xi).

The still incomplete The Hebrew University Bible (HUB) is based on the older but incomplete Aleppo manuscript, which lacks most of the Pentateuch.

The earliest translations of pre-masoretic Hebrew texts are the pre-Common era Aramaic Targumim and Old Greek texts. Coptic, Syriac and Latin translations came in the early Christian era, and with the spread of Christianity, translations into local languages began as early as the fifth century CE.

Funding: This research received no external funding. 
Acknowledgments: Thanks to Reinhard Pummer for putting this special issue on Samaritanism together.

Conflicts of Interest: The author declares no conflict of interest.

\section{References and Notes}

Anderson, Robert T. 1977. Studies in Samaritan Manuscripts and Artifacts. The Chamberlain-Warren Collection. Cambridge: American Schools of of Oriental Research.

Anderson, Robert. T. 1989. Samaritan Pentateuch. General Account. In The Samaritans. Edited by Alan D. Crown. Tübingen: Mohr, pp. 390-96.

Anderson, Robert. T., and Terry Giles. 2002. The Keepers. An Introduction to the History and Culture of the Samaritans. Peabody: Hendrickson.

Anderson, Robert. T., and Terry Giles. 2012. The Samaritan Pentateuch. An Introduction to Its Origin, History, and Significance for Biblical Studies. Atlanta: Society of Biblical Literature.

Ben-Hayyim, Zeev. 1957-1977. The Literary and Oral Tradition of Hebrew and Aramaic Amongst the Samaritans. (LOT). 5 vols. Jerusalem: The Bialik Institute and The Academy of the Hebrew Language. (In Hebrew)

Bowman, John. 1954. Transcript of the Original Text of the Samaritan Chronicle Tolidah. Leeds: University Oriental Society. Charlesworth, James H. 2009. 'What is a Variant? Announcing a Dead Sea Scrolls Fragment of Deuteronomy'. Maarav. 16/2, pp. 201-12 and (pls. ix-x) 273-74. Available online: http://shomron0.tripod.com/articles.html (accessed on 5 November 2019).

Charlesworth, James H. 2010. The Qumran Fragment of Deut. 27:4-6 -Building the Altar of the Almighty on Mount Gerizim-Declared Authentic. A.B.-The Samaritan News 1059-1060: 91-100.

Crown, Alan D. 1991. Redating the Schism between the Judeans and the Samaritans. Jewish Quarterly Review LXXXII: 17-50. [CrossRef]

Crown, Alan D. 2001. Samaritan Scribes and Manuscripts. Tübingen: Mohr Siebeck.

Crown, Alan D. 2004. Samaritan Judaism. In Encyclopaedia of Judaism. Edited by Jacob Neusner, Alan J. Avery-Peck and William S. Green. Leiden: Brill, pp. 2241-65.

Crown, Alan D., Abraham Tal, and Reinhard Pummer, eds. 1993. A Companion to Samaritan Studies. Tübingen: Mohr Siebeck.

Dotan, Aharon. 2001. תורה נביאים וכתובים. Biblia Hebraica Leningradensia. Leiden, Boston, Tokyo and Köln: Brill, Rev. ed. of תורה נביאים וכתובים. 1973. Tel Aviv: ADI publ. and the School of Jewish Studies of Tel Aviv University.

Florentin, Moshe. 1999. The Tulidah: A Samaritan Chronicle. Text, Translation and Commentary. Jerusalem: Yad Izhak Ben-Zvi. (In Hebrew)

Gaster, Moses. 1925. The Samaritans, Their History, Doctrines and Literature. The Schweich Lectures 1923. London: Oxford University Press.

Gesenius, Wilhelm. 1815. De Pentateuchi Samaritani. Origine, indole et auctoritate: Commentatio philologico-critica. Halle: Librariae Rengerianae.

Girón-Blanc, Luis F. 1976. Pentateuco Hebreo-Samaritano-Genesis. (Testos y estudios Cardenal Cisneros, 15). Madrid: Consejo Superior de Investigaciones Cientificas.

Harvainen, T., and Haseeb Shehadeh. 1994. How did Abraham Firkovich Acquire the Great Collection of Samaritan Manuscripts in Nablus in 1864? Studia Orientalia 73: 167-92.

Heckl, Raik. 2017. Überlegungen zu Form und Funktion der Zentralisationsformel im Konzept des samaritanischen Pentateuch, zugleich ein Plädoyer für die Ursprünglichkeit der masoretischen Lesart. Zeitschrift Für Altorientalische und Biblische Rechtsgeschichte 23: 191-208.

Hempel, J. 1934. Innermassoretische Bestätigungen des Samaritanus. Zeitschrift für die Alttestamentliche Wissenschaft 12: 254-74.

Hjelm, Ingrid. 2000. The Samaritans and Early Judaism: A Literary Analysis. Sheffield: Sheffield Academic Press.

Hjelm, Ingrid. 2004a. What do Samaritans and Jews Have in Common?: Recent Trends in Samaritan Studies. Currents in Biblical Research 3: 9-62. [CrossRef]

Hjelm, Ingrid. 2004b. Jerusalem's Rise to Sovereignty: Zion and Gerizim in Competition. London and New York: T\&T. Clark. Hjelm, Ingrid. 2012a. The Pentateuch that the Samaritans Chose?. A.B.-The Samaritan News no. 1119-1120, pp. 69-76, and no. 1121-1122, pp. 86-88. Reworked Danish ed. 2015: “The Pentateuch that the Samaritans Chose". Moderne fejlslutninger vedrørende den samaritanske Pentateuks oprindelse og karakteristika. Dansk Teologisk Tidsskrift 78: 225-42. 
Hjelm, Ingrid. 2012b. Review of Abraham Tal and Moshe Florentin, The Pentateuch. The Samaritan Version and the Masoretic Version. Edited and Annotated (חמישה חומשי תורה. נוסח שומרון ונוסח המסורה. Tel Aviv: The Haim Rubin Tel Aviv University Press, 2010; Hebrew), 765 pp. + Eng. Preface I-VII. Scandinavian Journal of the Old Testament 26/1: $145-51$.

Hjelm, Ingrid. 2015. Northern Perspectives in Deuteronomy and Its Relation to the Samaritan Pentateuch. In Deuteronomy: A Judean or Samari(t)an Composition. Perspectives on Deuteronomy's Origins, Transmission and Reception. Edited by Cynthia Edenburg and Reinhard Müller. Special Issue. Hebrew Bible and Ancient Israel 4: 184-204.

Hjelm, Ingrid. 2018. So-called Deuteronomic Addenda in the Samaritan Pentateuch Numbers 10-14 and 20-27. Where Do They Belong? In The Samaritans in Historical, Cultural and Linguistic Perspectives. Studia Samaritana 11; Studia Judaica 110. Edited by Jan Dusek. Berlin: de Gruyter, pp. 19-34. Available online: https://doi.org/10.1515/9783110617306-002 (accessed on 5 November 2019).

Joosten, Jan. 2015. Septuagint and Samareitikon. In From Author to Copyist: The Composition, Redaction and Transmission of the Hebrew Bible. Edited by Cana Werman. Winona Lake: Eisenbrauns, pp. 1-15.

Kartveit, Magnar. 2009. The Origin of the Samaritans. Leiden: Brill.

Knoppers, Gary N. 2013. Jews and Samaritans. The Origins and History of their Early Relations. Oxford: Oxford University Press.

Lowy, Simeon. 1977. Principles of Samaritan Bible Exegesis. Leiden: Brill.

Macchi, J. D. 1994. Les Samaritains histoire d'une légende: Israel et la province de Samarie. Le monde de la Bible 30. Geneve: Labor et Fides.

Macuch, Rudolf. 1969. Grammatik des samaritanischen Hebräisch. Berlin: W. de Gruyter.

Mendels, Doron. 1987. The Land of Israel as a Political Concept in Hasmonean Literature. Tübingen: Mohr.

Mendels, Doron. 1992. The Rise and Fall of Jewish Nationalism. New York: Doubleday.

Montgomery, James A. 1907. The Samaritans: The Earliest Jewish Sect: Their History, Theology and Literature. Philadelphia: John C. Winston, Reprinted. New York: Ktav, 1968.

Nelson, Richard D. 2002. Deuteronomy. A Commentary. Louisville: Presbyterian Publishing Corporation.

Nodet, Etienne. 1997. In Search of the Origins of Judaism: From Joshua to the Mishnah. Sheffield: Sheffield Academic Press, (Rev. ed. of Essai sur les origines du judaïsme: De Josué aux Pharisiens. Paris: Cerf.1992).

Noja, Sergio. 1989. The Samareitikon. In The Samaritans. Edited by Alan D. Crown. Tübingen: Mohr, pp. 408-12.

Pérez-Castro, Fr. 1953. El Séfer Abisha. Sefarad XIII: 119-29, Reprint: Das Kryptogramm de Sefer Abischa. Vetus Testamentum Supp. 7, 1960, pp. 52-60.

Pummer, Reinhard. 1995. 'The Samareitikon Revisited'. In New Samaritan Studies of the Société d'Études Samaritaines: Essays in Honour of G.D. Sixdenier, III-IV. Studies in Judaica, 5. Edited by Alan D. Crown and Lucy Davey. Sydney: Mandelbaum, pp. 381-455.

Pummer, Reinhard. 1998. The Greek Bible and the Samaritans. Revue des Etudes Juives 157: 269-358. [CrossRef]

Pummer, Reinhard. 2002. Early Christian Authors on Samaritans and Samaritanism: Texst, Translations and Commentary. Texts and Studies in Ancient Judaism, 92. Tübingen: Mohr Siebeck.

Pummer, Reinhard. 2007. The Samaritans and Their Pentateuch. In The Pentateuch as Torah: New Models for Understanding Its Promulgation and Acceptance. Edited by Gary N. Knoppers and Bernard M. Levinson. Winona Lake: Eisenbrauns, pp. 237-69.

Pummer, Reinhard. 2016. The Samaritans. A Profile. Cambridge: Eerdmans.

Purvis, James D. 1968. The Samaritan Pentateuch and the Origin of the Samaritan Sect. HSM, 2. Cambridge: Harvard University Press.

Sanderson, Judith E. 1986. An Exodus Scroll from Qumran: 4QpaleoExod ${ }^{m}$ and the Samaritan Tradition. HSS 30. Atlanta: Scholars Press.

Schenker, Adrian. 2010. Textgeschictliches zum Samaritanischen Pentateuch un Samareitikon. In Samaritans Past and Present: Current Studies. Edited by Menahem Mor and Friedrich V. Reiterer. Berlin and New York: Walter de Gruyter, pp. 105-21.

Schorch, Stefan. 2004. Die Vokale des Gesetzes. Die samaritanische Lesetradition als Textzeugin der Tora. 1. Das Buch Genesis. Berlin: Walter de Gruyter.

Schorch, Stefan. 2011. The Samaritan Version of Deuteronomy and the Origin of Deuteronomy. In Samaria, Samarians, Samaritans. Studies on Bible and Linguistics. Studia Samaritana 6. Edited by Joszef Zsengeller. Berlin: Walter de Gruyter, pp. 23-37. 
Schorch, Stefan. 2018. The Samaritan Pentateuch. A Critical Editio Maior, Vol. 3. Leviticus. Berlin: Walter de Gruyter. Schur, Nathan. 1989. The Modern Period (from 1516 A.D.). In The Samaritans. Edited by Alan D. Crown. Tübingen: Mohr, pp. 113-34.

Shehadeh, Haseeb. 1989. The Arabic Translation of the Samaritan Pentateuch. Critical Edition with Introduction. Vol. 1: Genesis-Exodus. Jerusalem: The Israel Academy of Sciences and Humanities.

Shehadeh, Haseeb. 2002. The Arabic Translation of the Samaritan Pentateuch. Critical Edition with Introduction. Vol.2: Leviticus-Deuteronomy. Jerusalem: The Israel Academy of Sciences and Humanities.

Shoulson, Mark. 2008. The Torah: Jewish and Samaritan Version Compared. (privately published).

Skehan, Paul W., Eugene Ulrich, and Judith E. Sanderson, eds. 1995. Qumran Cave 4: Palaeo-Hebrew and Greek Biblical Manuscripts. DJD IX. Oxford: Clarendon.

Tal, Abraham. 1980-1983. The Samaritan Targum of the Pentateuch: A Critical Edition. (3 vols). Tel Aviv: Tel Aviv University Press.

Tal, Abraham. 1994. The Samaritan Pentateuch, Edited According to MS 6 (C) of the Shechem Synagogue. Tel Aviv: The Chaim Rosenberg School for Jewish Studies.

Tal, Abraham, and Moshe Florentin. 2010. The Pentateuch-The Samaritan Version and the Masoretic Version. Tel Aviv: The Haim Rubin Tel Aviv University Press. (In Hebrew)

Tov, Emanuel. 1989. Protosamaritan Texts and the Samaritan Pentateuch. In The Samaritans. Edited by Alan D. Crown. Tübingen: Mohr, pp. 397-407.

Tov, Emanuel. 1992. Textual Criticism of the Hebrew Bible. Minneapolis: Fortress Press.

Tov, Emanuel, and Sidnie White. 1994. 4Q364. Reworked Pentateuch ${ }^{\mathrm{b}}$ (Plates XIII-XXI). In Qumran Cave 4. VIII Parabiblical Texts. Discoveries in the Judaean Desert, XIII. Edited by James Vanderkam, Emanuel Tov, Harold Attridge, Torleif Elgvin, Jozef Milik, Saul Olyan, John Strugnell and Sidnie White. Oxford: Clarendon, pp. 197-254.

Tsedaka, Israel. 2000. The Samaritan Torah Fully Punctuated According to Samaritan Readings. Holon: Samaritan Press, (Samaritan Script).

Tsedaka, Benyamim. 2011. The Comparative Jewish \& Samaritan Torah Versions. New Publication by A. Tal and M. Florentin is Not Recommended. A.B.-The Samaritan News 1078-79: 50-64.

Translated and Edited by Benyamim Tsedaka, and Sharon Sullivan. 2013, The Israelite Samaritan Version of the Torah: First English Translation Compared with the Masoretic Version. Grand Rapids. Mich.: Eerdmans.

Tsedaka, Avraham, and Ratzon Tsedaka, eds. 1961-1965. Jewish and Samaritan Versions of the Pentateuch-With Particular Stress on the Difference between Both Texts. Holon: Samaritan Press.

Ulrich, Eugene. 1994. 4Q Joshuaa and Joshua's First Altar in the Promised Land. In New Qumran Texts and Studies: Proceedings of the First Meeting of the International Organization for Qumran-Studies, Paris 1992. Edited by George J. Brooke. Studies on the Texts of the Desert of Judah 15. Leiden: Brill, pp. 143-52.

Ulrich, Eugene. 2017. The Samaritan and Masoretic Pentateuch. In Sibyls. Scriptures and Scrolls. John Collins at Seventy. Edited by Joel Baden, Hindy Najman and Eibert J. C. Tigchelaar. Leiden and Boston: Brill, pp. 1314-29.

Van Seters, John. 1994. The Life of Moses: The Yahwist as Historian in Exodus-Numbers. Kampen: Kok Pharos. Van Seters, John. 2013. The Yahwist. A Historian of Israelite Origins. Winona Lake: Eisenbrauns.

(C) 2020 by the author. Licensee MDPI, Basel, Switzerland. This article is an open access article distributed under the terms and conditions of the Creative Commons Attribution (CC BY) license (http://creativecommons.org/licenses/by/4.0/). 